\title{
Population Density of Piercing-Sucking Pests and their Associated Natural Enemies on Pepper, Capsicum annuum L. Plants under Greenhouse Condition at Ismailia Governorate, Egypt Ibrahim, M. M. A. \\ Plant Protection Res., Inst., Agric. Res. Center, Dokki, Giza, Egypt
}

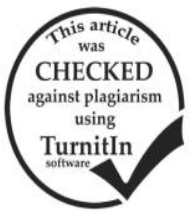

\section{ABSTRACT}

This study was conducted on pepper plants, Capsicum annuum L under greenhouse condition, in the farm of El Qassaseen Horticulture Research Station, Ismailia Governorate during the two successive winter seasons of 2013/2014 and 2014/2015 to survey the main piercing-sucking pests and associated natural enemies, also determine the population density and occurrence percentage for main species of pests and associated natural enemies. The obtained results showed that, the homopterous insects were the dominant piercing sucking pests recorded $85.87 \%$ (at the $1^{\text {st }}$ season) followed by order Acarina family Tetranychidae (the two spotted spider mite, Tetranychus urtica Koch.) recorded $14.32 \%$ (at the $2^{\text {nd }}$ season), but the order Thysanoptera, family Thrpidae (Onion thrips, Thrips tabaci Lind.) was occurred by lowest occurrence percentage $2.82 \%$ of the total numbers of surveyed pests recorded at the $2^{\text {nd }}$ season. While the Aphididae was the dominant homopterous family presented with $80.96 \%$ (at the $1^{\text {st }}$ season) of the total surveyed pests with three aphid species (green peach aphid, Myzus persicae (Sulz.), potato aphids, Macrosiphum euphorbiae (Thomas) and cotton aphids, Aphis gossypii Glov.), the Cicadellidae recorded lowest percentage of $0.99 \%$ at the ${ }^{\text {st }}$ season. The $M$. persicae found colonized plants terminals with high percentage of $72.80 \%$ than on leaves by $27.20 \%$; in contrast with $M$. euphorbiae which recorded $83.85 \%$ on leaves and $16.14 \%$ on terminals, while $A$. gossypii found on flowers only. The highest peak (as grand mean of the three aphid species) of 165.67 individuals /plant was recorded at $11^{\text {st }}$ March during the $1^{\text {st }}$ season. The highest parasitizem percentage on aphid species of 85.00 $\%$ was recorded at $22^{\text {nd }}$ June during the $2^{\text {nd }}$ season. The highest peaks for whitefly, Bemisia tabaci (Genn.) of 12.00 individuals / leaf were recorded at $8^{\text {th }}$ February and $16^{\text {th }}$ June during the $2^{\text {nd }}$ season. The leafhoppers, Empoasca spp. gave two weak peaks throughout the short activity period during the two study seasons. In the same trend, the population of $T$. tabaci recorded relatively high peak of 7.00 individuals/ leaf at $22^{\text {nd }}$ April during the $1^{\text {st }}$ season. Also, the $T$. urtica recorded the relatively high peak of 30.33 individuals/ inch ${ }^{2}$ at $22^{\text {nd }}$ April during the $1^{\text {st }}$ season. The highest peak of the general mean of insect predators (Coccinella spp. and Syrphus spp.) and that of grand mean of insect plus mite predators were recorded at $25^{\text {th }}$ March with 22.00 individuals/plant and 25.67 individuals/plant throughout the $1^{\text {st }}$ season for the two means, respectively. The peaks of predators were congruent in time with high activity period of pests that may be play main role in suppress piercing-sucking pests. The statistical analysis results showed that, the highest effect as explained variance, $\mathrm{EV} \%=67.92$ and $59.94 \%$ were recorded for the effect of each of parasitoid and total insect predators on aphids species during the $1^{\text {st }}$ season. So, it could be recommended to use each of parasitoids and predators to control piercing-sucking pests in greenhouses.

Keywords: greenhouse pepper plants, aphids, whitefly, leafhoppers, thrips, two spotted spider mites, associated natural enemies.

\section{INTRODUCTION}

Pepper (Capsicum annuum L) is one of the important economic, most popular and highly remunerative vegetable crops grown in most parts of the world; that for the nutritional values of fruits, mainly due to the fact that they are an excellent source of natural colors antioxidant and bioactive nutrients (carotenoids, vitamin $\mathrm{C}$ and phenolic compounds) (Ellaithy et al., 2015), Unlike many of the field problems, insects and animal pests problems are peculiar to greenhouse cultivation. Aphids, two spotted spider mite, thrips, whitefly, leafhoppers, caterpillars, leaf miner, gall midge, nematodes and snails are serious problems on vegetable crops under protected condition and present the major factor limiting pepper production. They multiply in large numbers under controlled temperature and relative humidity there by leading to significant crop loss (Giraddi et al., 2012). The pests of, Bemisia tabaci (Genn.); Tetranychus urtica Koch, Aphis gossypii Glov., Myzus persicae Sulz. and onion thrips, Thrips tabaci Lind. are infest and damage protected crops, particularly pepper, also, the greenhouses can be heavily infested by aphids, which seriously affect the yield and quality of the crop (Blackman \& Eastop, 2000; and Ben Halima, 2005). The piercing-sucking pests are very serious problem on pepper where both nymphs and adults suck the cell sap from leaves and tender parts thereby inducing premature senescence; also, excretes honeydew on which sooty mold grows and inhibits the photosynthesis in addition to indirect damage of spread viral diseases. The $\mathrm{M}$. persicae, Macrosiphum euphorbiae (Thomas) and A. gossypii and whitefly, T. vaporariorum and B. tabaci are principal pests of protected pepper crops in added to that, the M. persicae had highest incidence in pepper greenhouses followed by M. euphorbiae. (Sanchez et al., 2010; Beyon et al. 2011, Sanchez et al., 2011; Gavkare, 2012 and Dogan et al., 2016)

The present work aims to survey the main piercingsucking pests and their associated natural enemies on protected pepper cultivation, determine the population density, occurrence percentage for main species of pests, associated natural enemies and to clarify the relationships between pests and natural enemies to give the growers a picture of the risk about plant protection to be take attention to crop management.

\section{MATERIALS AND METHODS}

This study was conducted in greenhouses at El Qassaseen Horticulture Research Station, Ismailia Governorate during the two winter successive seasons of 2013/2014 and 2014/2015 to survey the piercing-sucking pests and associated natural enemies on protected pepper cultivation, determine the population dynamic and occurrence percentage for main species of pests and associated natural enemies under greenhouse condition $\left(27 \pm 3{ }^{\circ} \mathrm{C}\right.$ and $\left.70 \pm 5 \% \mathrm{RH}\right)$. One greenhouse of traditional area, $360 \mathrm{~m} 2$ with $40 \mathrm{~m}$ long, $9 \mathrm{~m}$ wide and $3.25 \mathrm{~m}$ height; consists of five rows is $1 \mathrm{~m}$ wide, $40 \mathrm{~m}$ long and distance between two seedling in the row is 50 $\mathrm{cm}$. The greenhouse was covered with UVI polyethylene sheets, cultivated with pepper seedling at 1 st week of November in the 1st season of 2013/2014 and 2nd week of October in the 2nd season of 2014/2015. The plants were received recommended package of Horticultural practices. Briefly, no pesticide was applied to pepper plants investigated throughout the study period. 


\section{Sampling technique:}

Weekly sample of 10 pepper plants terminals (3-5 $\mathrm{cm}$ ) replicated three times (30 terminals / sample) were chosen randomly and inspected actually in the greenhouse, in addition to 10 pepper fully expanded leaves (representing different plant strata) replicated three times (30 leaves / sample) were performed directly for flying insects by visual assessment in the morning hours when adults are less easily disturbed, collected in paper bags and transferred to laboratory to examine using binocular stereo microscope. The numbers of different stages of inspected pests, i.e., the aphids (cotton aphid, Aphis gossypii Glov., green peach aphid, Myzus persicae (Sulz.) and potato aphids Macrosiphum euphorbiae (Thomas) (Homoptera: Aphididae)); the whiteflies species (Bemisia tabaci (Genn.) and Trialeurodes vaporariorum (West.) (Homoptera: Aleyrodidae)); the leafhoppers species, (Empoasca spp. (Homoptera: Cicadellidae)); the onion thrips, (Thrips tabaci Lind.) (Thysanoptera: Thripidae)), and the two spotted spider mite (Tetranychus urtica Koch.) (Acarina: Tetranychidae)) were recorded throughout the study growing seasons as: number per cubic inch for $T$ urtica and number per leaf for the other pests.

In regard to associated natural enemies the numbers of aphids mummies, different stages of ladybird beetles (Coccinella spp.), hoverflies (Syrphus spp.) and phytoseiid predator mites species were recorded actually on sampled pepper plants in greenhouse and on sampled leaves in laboratory throughout the study growing seasons

\section{Statistical analysis:}

The obtained results were subjected to statistical analysis of correlation and regression as Little and Hills (1975) to clear the relationship between pests and natural enemies populations.

\section{RESULTS AND DISCUSSION}

1. Survey and occurrence percentages of piercingsucking pests:

Data in Table (1) revealed that, the homopterous insects were the dominant piercing-sucking pests infesting pepper plants and represented about 85.87 and $82.83 \%$ followed by the order Acarina family Tetranychidae presented 11.26 and $14.32 \%$ of the total numbers of surveyed pests during the two study seasons respectively. The Aphididae family was the dominant homopterous insect pests recorded with 80.96 and $75.46 \%$ of the total surveyed pests. Three aphid species, green peach aphid, M. persicae which recorded relatively highest occurrence ratio of 48.28 and $46.45 \%$ (terminals plus leaves) followed by potato aphids, $M$ .euphorbiae with 46.20 and $45.7 \%$ (terminals plus leaves) and cotton aphids, $A$. gossypii with 5.52 and $7.84 \%$ (on flowers only ) of the total surveyed Aphididae during the period of study, respectively. The Aleyrodidae family was occurred with relatively low percentages of 3.92 and $5.64 \%$ of the total homopterous. Two whiteflies species found namely, B. tabaci which present whole occurrence ratio of this family and $T$. vaporariorum which found in very low numbers during irregular periods. The Cicadellidae family recorded lowest homopterous percentages of 0.99 and $1.73 \%$ presented with leafhoppers species, Empoasca spp. during the two study seasons, respectively. The obtained results were in agreement with those of Beyon et al., 2011; Sanchez et al., 2011; Gavkare, 2012 and Dogan et al., 2016, who mentioned that, M. persicae, M. euphorbiae and A. gossypii and whitefly, T. vaporariorum and B. tabaci are principal pests of protected pepper crops and added that the $M$. persicae had the highest incidence in pepper greenhouses followed by $M$. euphorbiae. Also, that of Sandeep-Kaur et al., 2010 who stated that, B. tabaci was noticed only during the early season on pepper in greenhouse.

The results in Table (1) showed that, the two spotted spider mite, $T$. urtica came followed homopterous pests as occurrence ratio of 11.26 and $14.32 \%$ of the total surveyed pests, during the period of study, respectively. Also, the lowest occurrence percentages of 2.86 and $2.82 \%$ of the total surveyed pests were recorded for order Thysanoptera presented by family Thrpidae with one species, onion thrips, T. tabaci during the two study seasons, respectively. The obtained results are in agreement with those of Blackman and Eastop, 2000 and Ben Halima 2005, who reported that, the $B$. tabaci, T. urtica, A. gossypii, M. persicae and T. tabaci infested and damage protected crops, particularly pepper.

Table 1. Occurrence percentage of piercing-sucking pests infesting pepper plants under greenhouse condition $\left(27 \pm 3{ }^{\circ} \mathrm{C}\right.$ and $\left.70 \pm 5 \% \mathrm{RH}\right)$ during the two successive seasons of 2013/2014 and 2014/2015

\begin{tabular}{|c|c|c|c|c|c|c|c|c|c|c|c|c|c|c|}
\hline \multirow{3}{*}{$\begin{array}{l}\mathscr{E} \\
\text { छै } \\
\text { है }\end{array}$} & \multirow{3}{*}{ Parameters } & \multicolumn{8}{|c|}{ Aphids species } & \multirow{3}{*}{$\sum^{\frac{e}{0}}$} & \multirow{3}{*}{$\frac{\frac{2}{d}}{\frac{2}{2}}$} & \multirow{3}{*}{ 홀 } & \multirow{3}{*}{ 氡 } & \multirow{3}{*}{ 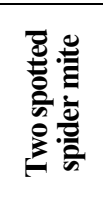 } \\
\hline & & \multirow{2}{*}{ 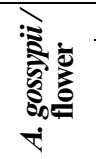 } & \multicolumn{3}{|c|}{ M. persicae } & \multicolumn{3}{|c|}{ M. euphorbiae } & \multirow{2}{*}{ 를 } & & & & & \\
\hline & & & Terminals & Leaves & Total & Terminals & Leaves & Total & & & & & & \\
\hline$\underline{m}$ & Seasonal total & 108.34 & 689.67 & 257.64 & 947.31 & 146.34 & 760.29 & 906.63 & 1962.28 & 95.01 & 24.00 & 2081.29 & 69.33 & 272.98 \\
\hline & Occurrence \% & $5.52 *$ & $72.8^{* * *}$ & $27.2^{* * *}$ & $48.28^{*}$ & $16.14 * * *$ & $83.85 * * *$ & $46.20 *$ & $80.96^{* *}$ & $3.92 * *$ & $0.99 * *$ & 85.87 & $2.86^{* *}$ & $11.26^{* *}$ \\
\hline 主 & Seasonal total & 121.33 & 542.00 & 176.66 & 718.66 & 154.31 & 552.66 & 706.97 & 1546.96 & 115.67 & 35.66 & 1698.29 & 58.01 & 293.65 \\
\hline & Occurrence $\%$ & $7.84^{*}$ & $75.42 * * *$ & $24.58 * * *$ & $46.45^{*}$ & $21.83^{* * *}$ & $78.17^{* * *}$ & $45.7^{*}$ & $75.46^{* *}$ & $5.64 * *$ & $1.73^{* *}$ & 82.83 & $2,82 * *$ & $14.32 * *$ \\
\hline
\end{tabular}

$*=$ Calculated depend on grand total of aphids species $* *=$ Calculated depend on total of each aphids species

$* * *=$ Calculated depend on grand total of surveyed pests

Obtained results in Table (2) cleared that, visual count of aphid mummies colored dark to light brown or a brassy brown with spherical round shape were recorded on pepper plants in relatively low numbers of 260 and 340 mummy/season during the two study seasons, respectively. The noticed mummies color gave clear indication about parasitoids species (Aphidius matricariae, A. colemani, Diaeretiella rapae, and Lysiphlebus testaceipes Cresson (Hymenoptera: Aphidiidae) which parasitized surveyed aphids species, as results of El-Heneidy \& Adly, 2009. The obtained results in Table (2) pointed the highest parasitizem percentages of 26.14 and $85.00 \%$ were recorded at 27 th May and 22nd June during the two study seasons, respectively; These results found in agreement with that of Sanchez et al., 2011 who found the parasitism percentages of all aphid species in greenhouses was low, Aphidius matricariae and Aphidius colemani being the most abundant parasitoids. 


\section{J. Plant Prot. and Path., Mansoura Univ., Vol.8 (9), September, 2017}

The results in Table (2) recorded two insect predators (Coccinella spp and Syrphus spp.) together presented 72.06 and $68.74 \%$ of the total numbers of surveyed predators during the period of study, respectively. Also, the phytoseiid predator mites, Neoseiulus and Euseius were found as dominant phytoseiid predator species but in relatively low numbers associated with pests on pepper plants presented 27.93 and $31.26 \%$ of the total numbers of surveyed predators during the two study seasons, respectively. The

Table 2. Occurrence percentage of natural enemies associated with pests on pepper plants under greenhouse condition $\left(27 \pm 3{ }^{\circ} \mathrm{C}\right.$ and $\left.70 \pm 5 \% \mathrm{RH}\right)$ during the two successive seasons of 2013/2014 and 2014/2015.

\begin{tabular}{|c|c|c|c|c|c|c|c|c|c|c|c|c|c|c|c|}
\hline \multirow{3}{*}{ 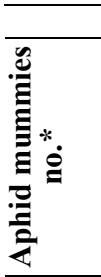 } & \multicolumn{6}{|c|}{ Season $2013 / 2014$} & \multicolumn{9}{|c|}{ Season $2014 / 2015$} \\
\hline & \multirow[b]{2}{*}{ 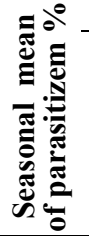 } & \multicolumn{6}{|c|}{ Predators } & \multirow[b]{2}{*}{ 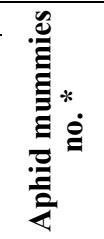 } & \multirow[b]{2}{*}{ 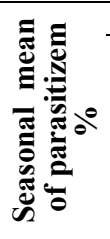 } & \multicolumn{5}{|c|}{ Predators } & \multirow[b]{2}{*}{ 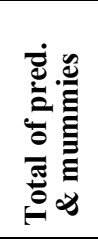 } \\
\hline & & 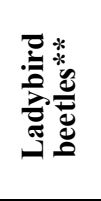 & 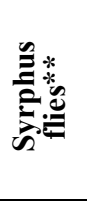 & 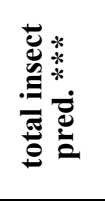 & 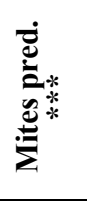 & 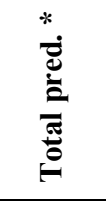 & 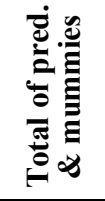 & & & 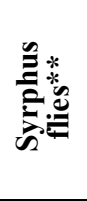 & 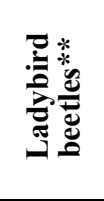 & 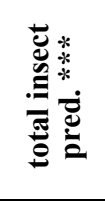 & 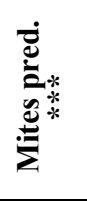 & $\frac{*}{20}$ & \\
\hline & \multicolumn{7}{|c|}{ Seasonal total } & \multicolumn{8}{|c|}{ Seasonal total } \\
\hline 500 & - & 143 & $\begin{array}{l}19.99 \\
\text { Occur }\end{array}$ & 163.32 & 63.32 & 26.64 & 486.64 & 340.00 & - & 47.33 & $\begin{array}{c}126.35 \\
\text { Occurr }\end{array}$ & 173.68 & 78.99 & 252.67 & 59 \\
\hline 3.43 & 9.64 & 87.76 & 12.24 & 72.06 & 27.93 & 46.57 & - & 57.36 & 28.81 & 27.25 & 72.75 & 68.74 & 31.26 & 42.63 & - \\
\hline
\end{tabular}

obtained results found in agreement with those of AnaPineda, 2008 who cleared that, nine species of aphidophagous syrphids were found as larvae, preying on aphids on sweet pepper plants. Also, with those of Gallardo et al., 2005 who mentioned that the Neoseiulus predator mites was found as dominant phytoseiid predator mite's species associated with phytophagous mite on pepper plants in greenhouse
2. Population density of major pests:

- Aphids species:

The data illustrated in Figs (1\&2) showed that, the activity peaks of listed aphid species were varied as a number, time, and values. The aphid species populations were oscillated and fluctuated on different pepper plants parts drawing numbers of peaks varied as aphid species and plant parts. The cotton aphid, $A$. gossypii recorded two peaks

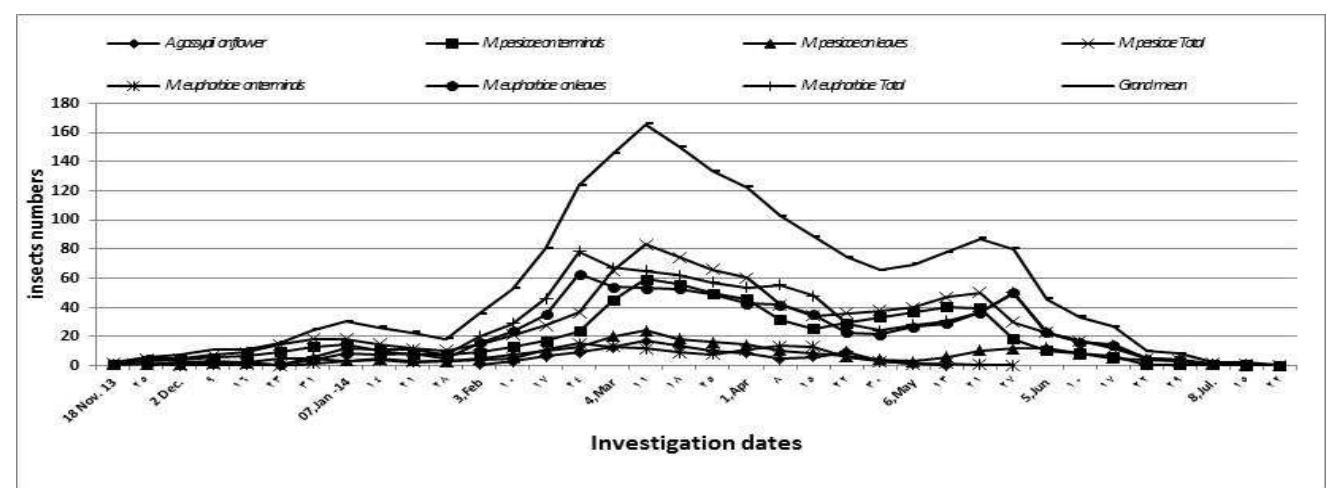

Fig. 1. Population fluctuation of aphid species infested pepper plants in greenhouse, 2013/2014 Season

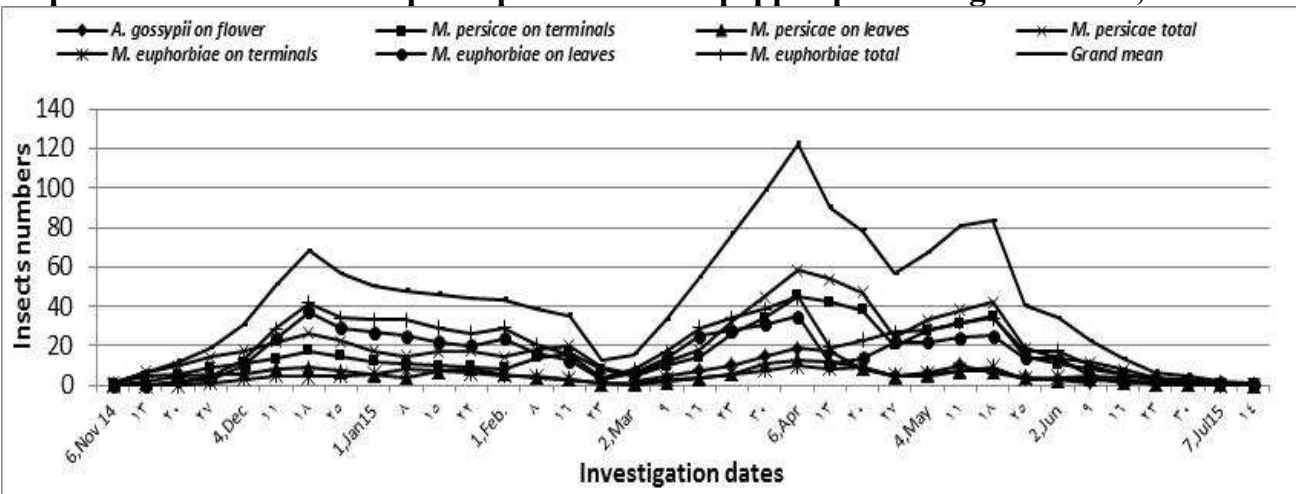

Fig. 2. Population fluctuation of aphid species infested pepper plants in greenhouse, 2014/2015 Season

The green peach aphid, M. persicae found colonized the terminal part and leaves of pepper plant all over the two throughout activity period extended from, 3rd February till 13rd may during the 1 st season of 2013/2014, the peaks of 17.33 and 9.67 individuals/ flower were regarded at 11th March and 22nd April, while at the 2nd season of 2014/2015 the activity period extended from 2 nd march till 9th June patterned by two peaks at 6th April and 11th may with mean numbers of 19.00 and 10.33 individuals / flower for the two peaks, respectively. 
peaks on terminals of $14.67,59.33$ and 40.66 individuals/ terminal were recorded at 7th January, 11th march and 13 may; while on leaves the peaks of 5.33, 24.00, and 12.33 individuals/ leaf were recorded at 31st December, 11th march and 5th June for the three peaks, respectively. In case of general mean of $M$. persicae on the two plant parts the three peaks of 18.66, 83.33 and 50.34 individuals/plant recorded at 31st December, 11th March and 21st May for the three peaks, respectively. In the second season, $M$. persicae recorded four peaks on each of the two plant parts and five peaks as general mean, the peaks of $17.67,16.67$, 45.33 and 35.00 individuals/ terminal were recorded at 18th December, 16th February, 6th April and 18th May; while on leaves the peaks of 9.00, 8.34,13.00 and 7.33 individuals/ leaf were recorded at 18th December, 22nd January, 6th April and 18th May; in case of general mean of $M$. persicae on the two plant parts the peaks recorded at 18th December, 22nd January, 16th February, 6th April and 18th May with general mean of 26.66, 16.67, 20.00, 58.33 and 42.34 individuals/plant for the five peaks, respectively Figs (1\&2).

The potato aphid, $M$. euphorbiae found colonized terminal part and leaves of pepper plant all over the two investigation seasons; recorded three peaks on terminals, four peaks on leaves and as general mean during the $1 \mathrm{st}$ season. The three peaks on terminals of $4.00,15.33$ and 13.66 individual/ terminal were recorded at 14th January, 24th February and 8th April; while the four peaks on leaves of 2.67, 8.67, 63.00, and 50.00 individuals/ leaf were recorded at 9th December, 7th January, 24th February and 27 th May; in case of general mean, the five peaks of 3.66 , $12.00,78.33,55.67$ and 50.34 individuals/plant were recorded at 9th December, 7th January, 24th February, 8th April and 27th May for the five peaks, respectively. In the 2nd season, the aphids numbers showed four peaks on terminals with $5.00,8.00,10.00$ and 9.33 individuals/ terminal which recorded at 11th December, 8th January, 6th April and 18th May; while on leaves the peaks recorded at 25th December, 1st February, 6th April and 18th May with mean numbers of 37.33, 24.00,35.00 and 25.00 individuals/ leaf; also, the peaks of general mean were recorded at 18th December, 1st February, 6th April and 18th May with mean numbers of 41.66, 29.00, 45.00, and 34.34 individual/plant for the four peaks of $M$. euphorbiae on pepper plants , respectively Figs (1\&2).

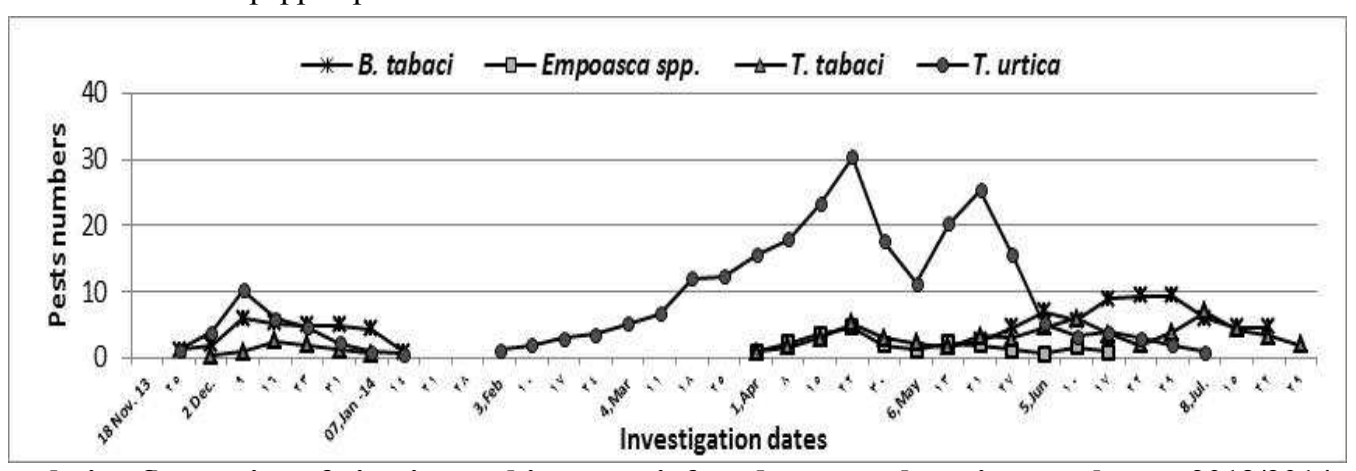

Fig. 3. Population fluctuation of piercing sucking pests infested pepper plants in greenhouse, 2013/2014 season

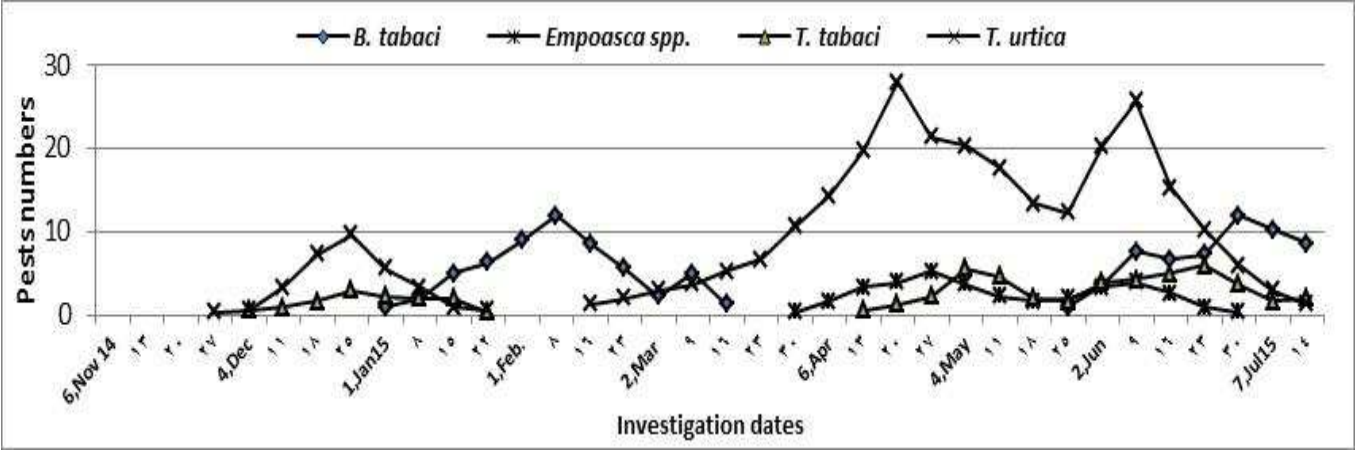

Fig. 4. Population fluctuation of piercing sucking pests infested pepper plants in greenhouse, 2014/2015 season.

As grand mean data illustrated in Figs (1\&2), cleared that, the grand mean of three aphids species revealed three peaks during each of the two study seasons. During the 1st season, the peaks of 30.34, 165.67 and 87.34 individuals/plant were recorded at 7 th January, 11th March and 21st May, while during the 2nd one the peaks of 68.33, 122.33 and 83.33 individuals/plant were recorded at 18th December, 6th April and 18th May for the three peaks respectively.

Generally, it could be concluded that, M. persicae found colonized the terminals of pepper plants with highly percentage $(72.80 \%)$ than on leaves $(27.20 \%)$ in contrast with $\mathrm{M}$. euphorbiae which found on leaves $(83.85 \%)$ more than plants terminals $(16.14 \%)$, while the cotton aphids found on flowers only. The total mean numbers of the three aphid's species was relatively high during the first season (1962.28 individuals/plant) than the second one (1546.96 individuals/plant), that found in contrast with other pests which recorded relatively high numbers at the second season more than the first one. The obtained results found agree these of Gavkare 2012 and Gavkare et al., 2014 who showed that, M. persicae is a very serious pest of the pepper at different times under protected environment at different tested locations in Himachal Pradesh. Also that of, Gavkare et al., 2015 who mentioned that, M. euphorbiae is one of the most problematic aphids in protected environments worldwide.

The statistical analysis results in table (3) revealed highly significant positive correlation coefficient between grand total mean of the three aphids species and aphid 
mummies numbers $(\mathrm{r}=0.82 * *)$ during 1 st season, while negative insignificant correlation coefficient $(r=-0.04 n s)$ was fulfill during the 2 nd season. Also, the results pointed out that the numbers of parasitoids was influenced aphids numbers and vice versa regardless of the signal of regression, where highly significant effect as explained variance $(\mathrm{EV} \%)$ of $67.92 \%$ was noticed during the 1 st season,. In the same trend, highly significant positive correlation $(\mathrm{r}=0.774 * *)$ was realize between the grand total mean of aphids species and total insect predators with highly significant effect $\mathrm{EV}=59.94 \%$ during the 1st season.

Table 3. Results of simple correlation, simple and partial regression, and explained variance between mean numbers of pests and natural enemies during the two successive seasons of 2013/2014 and 2014/2015.

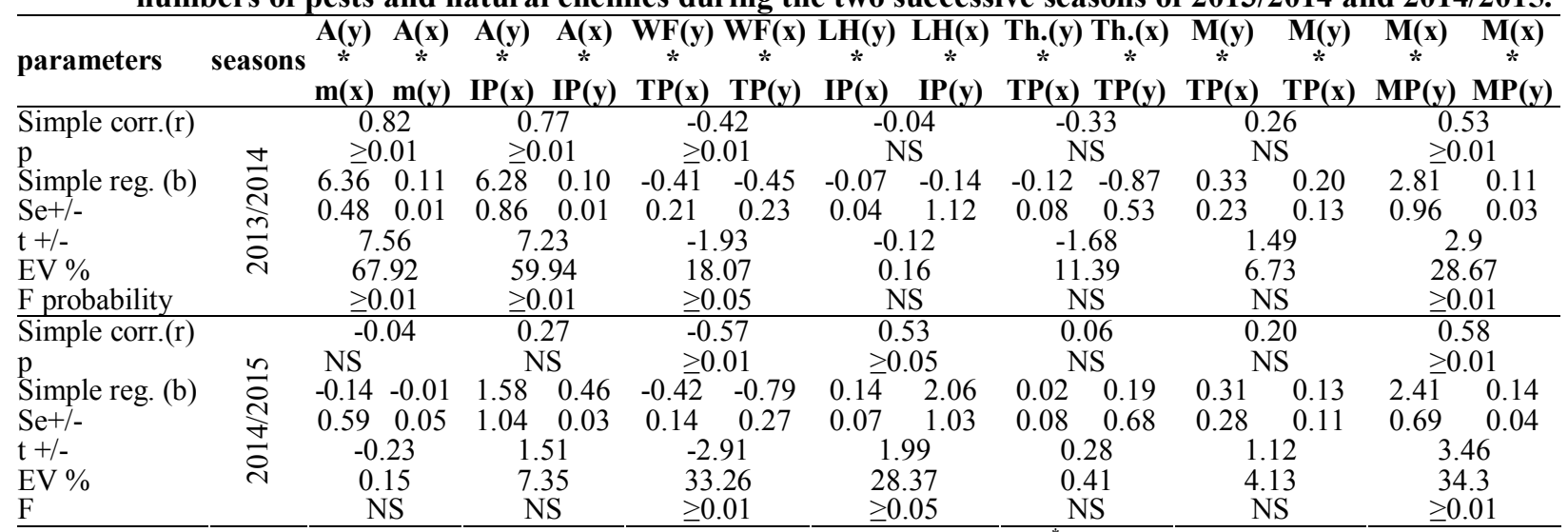

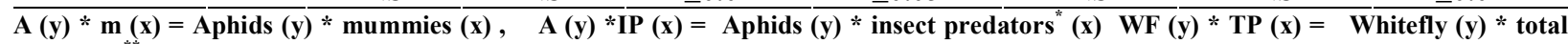
predators $^{* *}(x), \quad$ L.H $(y) * I P(x)=$ Leafhoppers $(y) *$ insect predators $(x) \quad$ Th. $(y) *$ TP $(x)=$ Thrips $(y) *$ total predators $(x)$ M $(y) *$ TP $(x)=$ Mite $(y) *$ total predators $(x), M(y) *$ MP $(x)=$ Mite $(y) *$ mite predators $(x)$ and inverse that from $(x)$ to $(y)$ for regression. insect predators $=$ total of lady bird beetles + Syrphus flies ${ }^{* *}$ total predators $=$ total of insect predators + predator mite $(P M)$. $\geq 0.01=$ highly significant correlation coefficient. $\geq \mathbf{0 . 0 5}=$ only significant correlation coefficient. NS= non-significant correlation coefficient

- Whitefly, B. tabaci :

The obtained results in Figs $(2 \& 4)$ cleared that, the population of whitefly was oscillated and fluctuated on pepper plants recorded three peaks throughout two activity periods extended from, 25th November till 14th January and from 13th may till 22nd July during the 1st season of 2013/2014, the peaks of 6.00, 7.00 and 9.33 individual/ leaf were regarded at 9th December 5th June, and 29th June, respectively. In the 2nd season of 2014/2015, four peaks were observed throughout two activity period extended from 1st January till 16th march and from 25th may till 14th July, the peaks of $12.00,5.00,7.66$ and 12.00 individuals / leaf were recorded at 8th February, 9th march and 16th June for the four peaks, respectively. The obtained results found agree these of Sandeep-Kaur, et al., 2010 who stated that $B$. tabaci was noticed only during the early season on pepper in greenhouse.

The statistical analysis in Table (3) showed that highly significant negative correlation coefficient between mean numbers of whitefly and total numbers of predators $(\mathrm{r}$ $=-0.42^{* *}$ ) during the 1 st season, negative highly significant correlation coefficient $(r=-0.57 * *)$ during the 2 nd one. Also, the results realized that the predators were influenced whitefly numbers, where, the relatively high effect as explained variance (EV \%) of $33.26 \%$ was deduced during the 2nd season.

\section{- Leafhoppers Empoasca spp.:}

The obtained results in Figs $(2 \& 4)$ showed that the occurred of leafhoppers population on pepper plants with low numbers patterned two weak peaks throughout one short activity period extended from 1st April till 17th June during the season of 2013/2014, the peaks were noticed at 22nd April and 13th may with 4.67 and 2.33 individuals/ leaf, respectively. In the same trend, two weak peaks of 5.33 and 4.00 individuals / leaf were observed throughout the short activity period of 2014/2015 season at 27th April and 9th June for the two peaks, respectively.

The results of statistical analysis in Table (3) revealed insignificant negative correlation coefficient between the mean numbers of leafhoppers and total numbers of predators $(\mathrm{r}=-0.04 \mathrm{~ns})$ during 1st season, positive significant correlation coefficient $\left(\mathrm{r}=0.53^{*}\right)$ during the 2 nd one. Also, the predators influenced leafhoppers numbers, where the relatively high significant effect as explained variance (EV $\%$ ) of $28.37 \%$ was recorded during the 2 nd season.

\section{- Onion thrips T. tabaci:}

The data presented in Figs $(2 \& 4)$ showed that two activity periods, four and three peaks were recorded for $T$. tabaci during the two study seasons, respectively. During the 1 st season the periods were extended from 2nd December till 7th January and from 1st April till 29th July, in a while the four peaks of 2.67, 5.33, 6.00 and 7.00 individuals/ leaf were recorded at 16th December, 22nd April, 10th June and 8th July for the inspected peaks, respectively. During the 2nd season the two activity periods of thrips were extended from 4th December till 22nd January and the 2nd period from 27th April till 29th July with three peaks of 3.00, 5.67 and 6.00 individuals/ leaf set at 25th December, 4th May and 23rd June for the inspected peaks, respectively. The obtained results found agree these of Ben Halima, 2005 who stated that the onion thrips $T$. tabaci infested and damage protected crops, particularly pepper

The statistical analysis results in Table (3) revealed that insignificant negative correlation coefficient between mean numbers of thrips and total numbers of predators $(\mathrm{r}=$ $0.33 \mathrm{~ns}$ ) during 1st season, positive insignificant correlation coefficient $(r=0.064 n s)$ during the 2 nd one. Also, the results pointed that the predators was influenced thrips numbers, where, insignificant relatively high effect as explained variance (EV \%) of 11.39 was noticed during the 1 st season. 
- Two spotted spider mite, T. urtica:

The population of the two spotted spider mites on pepper plants as seen in Figs (2\&4) was oscillated, fluctuated and drawn out four peaks throughout the two activity periods extended from, 25th November till 14th January and from 3rd February till 8th July during 2013/2014 season; The peaks were realized at 9th December, 22nd April, 21st May and 17th June with 10, 33, $30.33,25.33$ and 4.00 individuals/ inch2, respectively. Also, at 2014/2015 season, three peaks were appeared throughout the two activity period which extended from 27th November till 22nd January and from 16th February till 14th July; the peaks recorded at 25th December, 20th April and 9th June with mean numbers of 9.67, 28.00 and 25.67 individuals / inch2 for the three peaks, respectively. The obtained results found agree with these of Giraddi et al., 2012) who reported that, the two spotted spider mite, $T$. urtica infest and damage protected crops; particularly pepper

The results of statistical analysis presented in Table (3) cleared that insignificant positive correlation coefficient between mean numbers of mite and total numbers of predators $(\mathrm{r}=0.26 \mathrm{~ns}$ and $0.20 \mathrm{~ns}$ during the period of study, respectively. Also, the results pointed that, the predators was influenced the numbers of $T$. urtica, where insignificant effect as relatively low explained variance (EV \%) ranged 4.13 to $6.73 \%$ was noticed. On the other hand the relationship between the two spider mite and predator mite revealed highly significant positive correlation coefficient, $\mathrm{r}$ $=0.53 * *$ and $0.58^{* *}$ during the two seasons, respectively. Also, the results pointed that the predator mites were influenced the numbers of the two spider mite, where highly significant effects of predator mites as explained variance (EV\%) of $34.30 \%$ were noticed during the 2 nd seasons.

Generally, the relatively highest numbers of aphids, leafhoppers and two spotted spider mite were recorded during March and April, while the relatively highest numbers of each of whitefly and thrips noticed during June, that during the flowering and fruiting period resulting in a shortage of both quality and quantity of yield. The obtained results found agree with these of Saad, 2002 in Egypt, who stated that vegetables under protected cultivation are attacked by numerous insects and mites caused serious damage and high yield loses. While the results found in partially agree with those of Roopa and Nandihalli, (2009) who reported three peaks of incidence of mite, two in AprilMay and one in November. While the results found in contrast with these of Amna et al., (2012), who stated that, the maximum population of whitefly were observed during May, but maximum population of spider mites and thrips were observed during June.

\section{Population density of associated natural enemies:}

\section{- Aphid mummies:}

The illustrated data in Figs (5\&6) cleared relatively low numbers of aphid parasitoids during the 2013/2014 season, that throughout activity period extended from 9th December till 22nd June with three mummies peaks of 8.33, 20.00 and 21.00 mummies/plant which realized at 7 th January, 25th March and 27th May, respectively. The unexpected results showed that, the peaks of parasitism percentages were not in timing with that of mummies, which may be return to the effect of other factors. The relatively high parasitizem percentages of 28.39 and $26.14 \%$ were noticed early in the 1st season at 31st December and late in the season at 27th May, respectively. During 2014/2015 season, the activity period of parasitoids was extended from 27 November till 14 July with five peaks realized at 4th December, 8th February, 9th March, 27th April and 2nd June with mean numbers of 2.33, 24.33, 8.33, 16.00 and 22.67 mummies /plant. In the same trend, the highest parasitizem percentages of $85.00 \%$ were noticed late in the season at 16 June. The obtained results found in agree those of Sanchez et al., (2011) who reported that, the parasitism of all aphid species in greenhouses was relatively low.

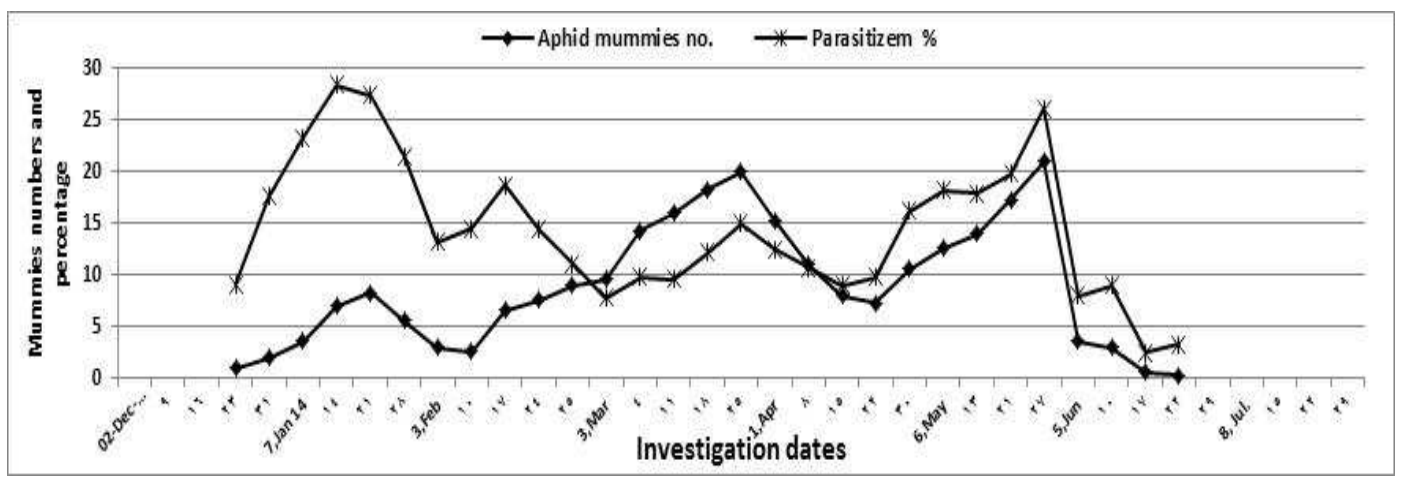

Fig. 5. Mean numbers of aphid's mummies and parasitizem \% on pepper plants in greenhouse 2013/2014 season.

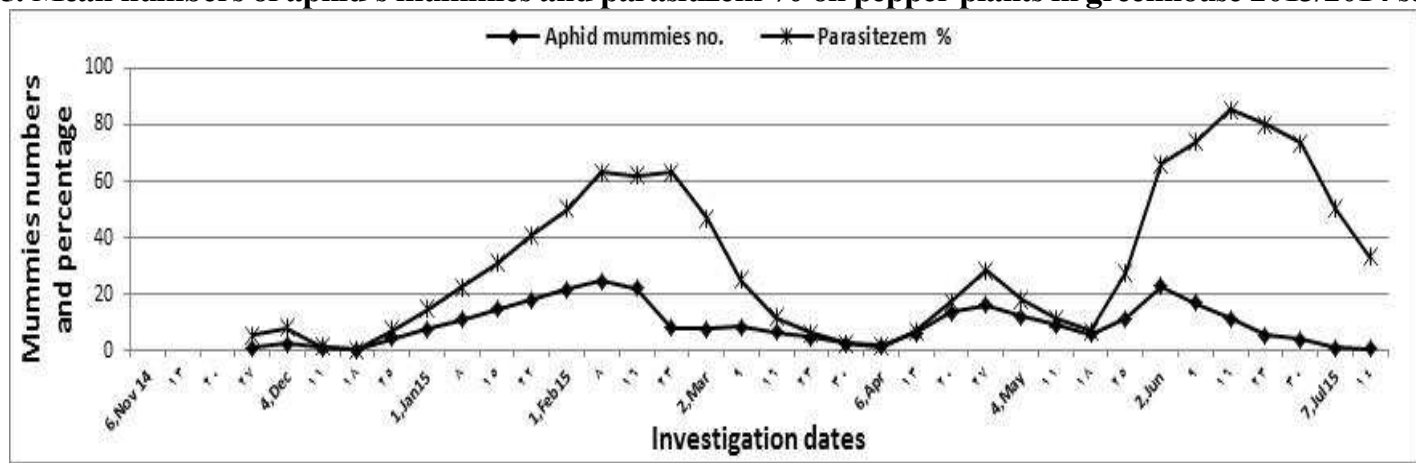

Fig. 6. Mean numbers of aphid's mummies and parasitizem \% on pepper plants in greenhouse 2014/2015 season 
- Insect predators:

As seen in Figs $(7 \& 8)$ there were two insect predators found associated with the scouted pests on pepper plant; the ladybird beetles, Coccinella spp. were the dominant insect predator recorded activity periods extended from $31^{\text {st }}$ December till $6^{\text {th }}$ May at the $1^{\text {st }}$ season and from $7^{\text {th }}$ January till $27^{\text {th }}$ June at the $2^{\text {nd }}$ one with two and three peaks throughout the two seasons, respectively. The two peaks of the $1^{\text {st }}$ season were recorded at $24^{\text {th }}$ February and $25^{\text {th }}$ March with 17.33 and 22.00 individuals /plant, respectively. During the $2^{\text {nd }}$ season, the three peaks were recorded at $15^{\text {th }}$ January, $9^{\text {th }}$ March and $4^{\text {th }}$ May with $6.00,17.33$ and 6 individuals /plant, respectively. The second insect predator Syrphus spp. found in relatively low numbers during two short activity periods at the $1^{\text {st }}$ season and one activity periods at the $2^{\text {nd }}$ one with two peaks for each of the two seasons. The two peaks of the $1^{\text {st }}$ season were recorded at $10^{\text {th }}$ February and $13^{\text {th }}$ may with 3.00 and 2.67 individual /plant, while during the $2^{\text {nd }}$ season, the peaks were recorded at $23^{\text {rd }}$ February and $16^{\text {th }}$ June with 6.00 and 7.00 individual /plant, respectively.

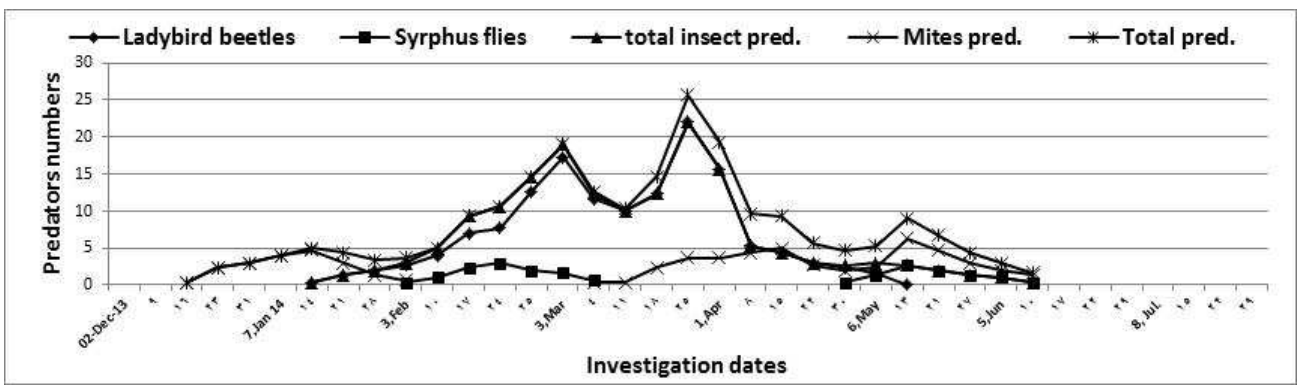

Fig. 7. Seasonal abundance of predators associated with pepper pests in greenhouse during 2013/2014 season.

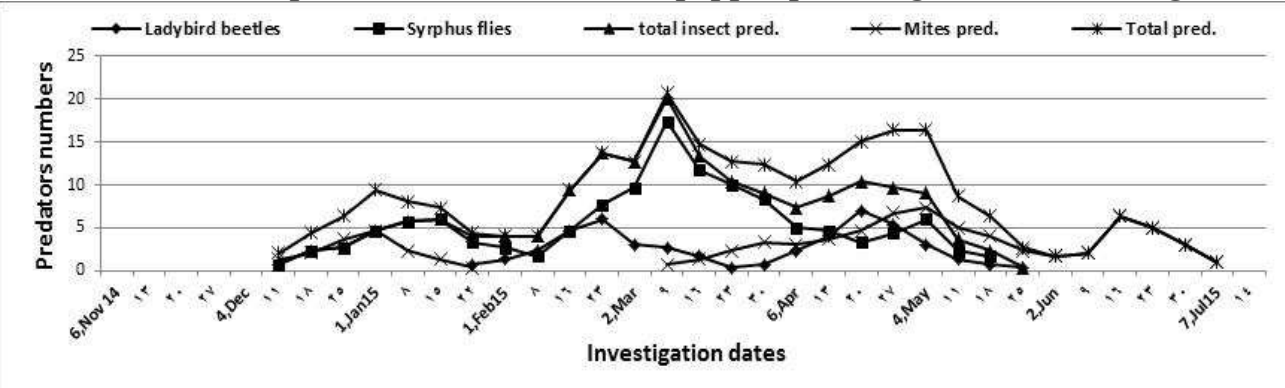

Fig. 8. Seasonal abundance of predators associated with pepper pests in greenhouse during 2014/2015 season.

\section{- Predator mite:}

The obtained results in Figs (7\&8) revealed that, the total mean of phytoseiid predator mites were found in relatively low numbers, recorded two activity periods with three relatively weak peaks during each of the two study seasons. The peaks of the first season were recorded at 31st December, 15th April and 13th May with 4.67, 5.00 and 6.33 individuals/leaf, respectively. In the same trend, the peaks of the second season were recorded at 1st January, 4th May and 16th June with 4.67, 7.33 and 6.33 individuals/leaf, respectively

Generally, the highest parasitizem percentage of $85.00 \%$ was noticed late in the 2 nd season at 22 June. Also, the highest peak of the total of the two insect predators of 22 individuals /plant and that of grand total (the total of the insect predators plus the mite predators) of 25.67 individuals /plant were pointed at 25th March during the two study seasons. The peaks of predators were congruent in time with the relatively high activity of pests during the study period that may be play main role in suppress piercing-sucking pests. The obtained results are agree with these of Riddick, 2017 reported that, the combined action of ladybirds and hymenopteran parasitoids could have a net positive effect on aphid population suppression. In addition to that of Valério et al., 2007 who stated that the Coccinella spp. suppress primarily A. gossypii and A. craccivora on sweet pepper (C. annuum) and added that, the parasitoid Aphidius colemani suppress M. persicae. In the same trend, Obrycki \& Kring, 1998 and Lara De Backer et al., 2015 who cleared that the predators ability were affected by aphid population and the aphids population had negative correlation with predator numbers

\section{REFERENCES}

Amna M. H.; S.M. Maklad, M.K. Abolmaaty, N. Y. Hassanein and Abd El Ghafar (2012): Impact of type of greenhouse cover sheets on certain major cucumber pests under protected cultivation. New York Sci. J., 5(7):19-24

Ana Pineda and Ma Ángeles Marcos-García (2008): Seasonal abundance of aphidophagous hoverflies (Diptera: Syrphidae) and their population levels in and outside Mediterranean sweet pepper greenhouses. Ann. Ent. Soc. of America, 101 (2): 384-391.

Ben Halima Kamel M. (2005): Biological control of Aphis gossypii on pepper plant using Coccinella algerica. Com. Appl. Biol. Sci. Ghent Univ., 70: 737-743.

Blackman RL and V.F. Eastop (2000): Aphids on the world's crops. an identification and information guide, The Natural History Museum.

Byeon, Y.W.; T.M. Midori, J.H. Jeong and Y.M. Cho (2011): Functional responses of aphid parasitoids, Aphidius colemani (Hymenoptera: Braconidae) and Aphelinus asychis (Hymenoptera: Aphelinidae). Biocont. Sci., Tech., 21(1): 57- 70. 
Dogan, A.; F. Erler, M. Erkan1, A. Ozgur Ates, H. Sule Sabanci, and E. Polat1 (2016): Microbial based Production System: A Novel Approach for Plant Growth and Pest and Disease Management in Greenhouse-grown Peppers (Capsicum annuum L.). J. Agr. Sci. Tech., 18: 371-386.

El-Heneidy, A. H. and D. Adly (2009): Discrimination among aphid parasitoids through characteristics of their mummies. Egyptian, J. Bio. Pest Cont., 19(1):37-40.

Ellaithy, A.Y.M.; M. R. Shafeek, Hoda .E. Hussein, and G. M. Abo-Elellal (2015): Piercing-sucking pests, growth and yield of sweet pepper cultivars as affected by alternative covers under plastic tunnel conditions. Inter. J. Chem., Tech. Res., 8 (9): 149-161.

Gallardo A.; C. Vasquez, J. Morales, J. Gallardo (2005): Biology and natural enemies of Tetranychus urtica in sweet pepper. Manejo Integrado de Plagasy Agroecologia. Centro Agronomico Tropical de Investigacion Ensenanza, Turrialba, Costa Rica, 74: 34- 40.

Gavkare, O. J. (2012): Biology and management of Myzus persicae (Sulzer) on Capsicum annuum L. under protected cultivation. M.Sc. Thesis, CSK Himachal Pradesh Krishi Vishvavidyalaya, Palampur, India, $81 \mathrm{pp}$.

Gavkare, O.; S. kumar, Y. Shinde and S. P. Bhopale (2014): Abundance of the Myzus persicae (Sulz.) under protected environment in Himachal Pradesh, India. J. Indust., Pollut. Cont. 30(2): 285-287.

Gavkare, O.; P. L. Sharma, and G. Japoshvili (2015): Parasitization of the potato aphid, Macrosiphum euphorbiae (Thomas), by Aphelinus asychis Walker in greenhouses in India. J. Agric. Urban Ent., 310: 47-51.

Giraddi , R. S.; S. M. Mantur, R. K. Patil, C. P. Mallapur, K. V. Ashalatha (2012): Population dynamics and extent damage of pests of Capsicum under protected cultivation Karnataka J. Agric. Sci.,25 (1) : (150-151)
Lara De Backer, Felix L. Wäckers, Frédéric Francis and François J. Verheggen (2015): Predation of the peach aphid Myzus persicae by the mired predator Macrolophus pygmaeus on sweet peppers: effect of prey and predator density. Insect, 6, 514-523

Little, T. M. and F. J. Hills (1975): Statistical methods in agricultural research available from U.C.D. Book store, Univ. of California, Davis: 241pp.

Obrycki, J.J. and T.J. Kring (1998): Predaceous Coccinellidae in biological control. Ann. Rev. Ent., 43, 295-321.

Roopa, S. P. and B. S. Nandihalli (2009): Seasonal incidence of mite pests on brinjal and chilli. Karnataka J. Agric. Sci., 22: 729 - 731.

Riddick, E.W. (2017): Identification of conditions for successful aphid control by ladybirds in greenhouses. Insects, 8, (38): 33-38.

Saad, H. N., (2002): Economics of the integrated pest management of certain insect and animal pests on most important vegetable crops production under plastic green house. MSc. Thesis, Moshtohor, Zagazig Univ., Banha Branch, 143 PP.

Sanchez, J. A., M. La-Spina, J. M. Michelena, A. Lacasa and A. H. D. Mendoza(2010): Ecology of aphid pests of greenhouse pepper crops and their parasitoids. Biocon. Sci. Tech., 21: 171-188.

Sanchez, J.A.; M. La-Spina , J.M. Michelena , A. Lacasa and A. Hermoso de Mendoza (2011): Ecology of the aphid pests of protected pepper crops and their parasitoids. J. Biocont. Sci., Tech., 21 (2): 171-188.

Sandeep Kaur, Sukhjeet Kaur, R. Srinivasan, D. S. (2010): monitoring of major pests on cucumber, sweet pepper and tomato under net-house conditions in Punjab, India Pest Management in Horticultural Ecosystems, 16(2):148-155.

Valério, E.; A. Cecílio, A. Mexia (2007): Interactions between aphid species and beneficial organisms in sweet pepper protected crop. Bol. Sanid. Veg. Plagas, 33, 143-152.

\section{الكثافة العددية للآفات الثاقبة الماصة والاعداء الحيوية المصاحبة لها علي نباتات القلقل تحت ظروف البيوت

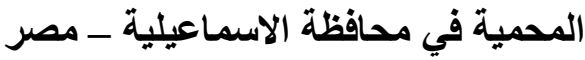 محمد محمد احمد ابراهيم

$$
\text { معهد بحوث وقداية النباتات ــ مركز البحوث الزراعية ـ الاقيم- جيزة - مصر }
$$

أجريت هذه الدراسة علي نباتات الفلفل تحت ظروف البيوت المحمية في مزرعة محطة بحوث البساتين بالقصاصبن - محافظة الاسماعلية خلال موسمبن متتاليين

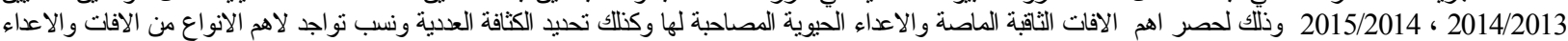

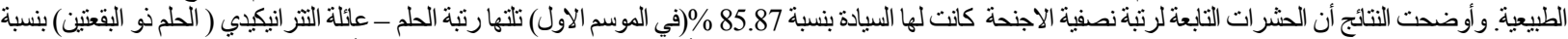

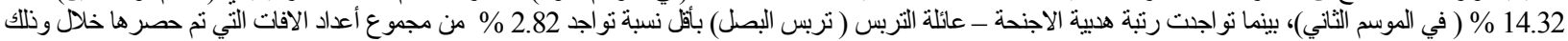

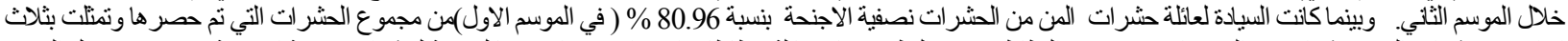

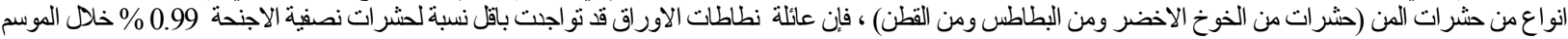

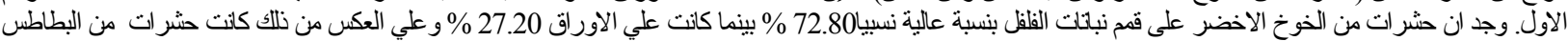

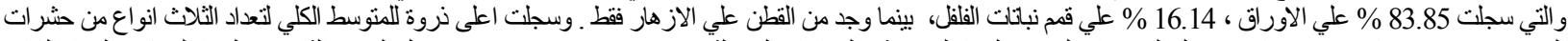

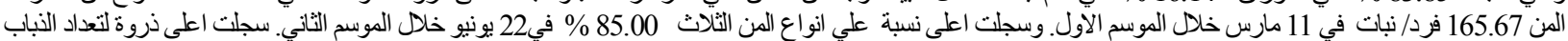

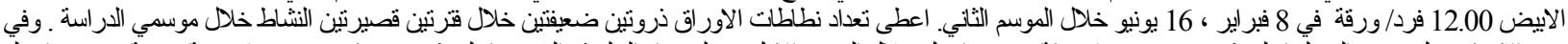

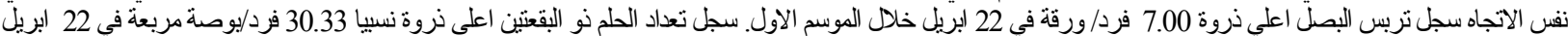

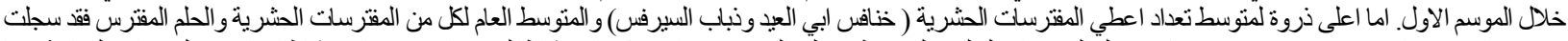

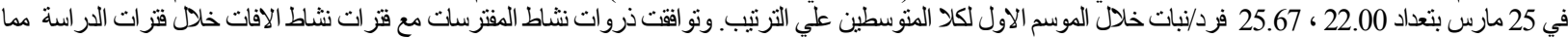

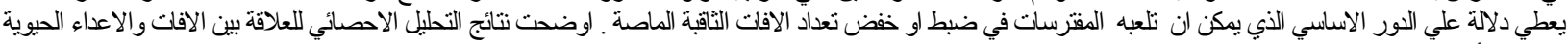

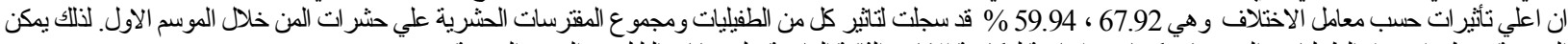

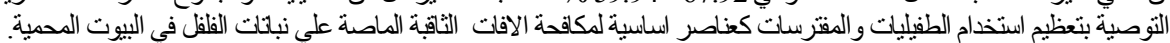

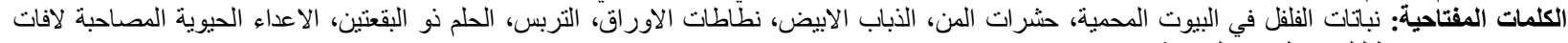
الفلفل في البيوت المحمية. 